\title{
EFFECT OF ETHANOL EXTRACT OF PICRIA FEL-TERRAE LOUR. LEAVES ON TRIGLYCERIDE AND CHOLESTEROL LEVELS OF WHITE RATS
}

\author{
URIP HARAHAP*, MARIANNE, YUANDANI, HAFIZA MITHA AGUSTYA, DIRA UMMUL AZIZAH, \\ SYARI WIDIA ALFIAH
}

Department of Pharmacology, Faculty of Pharmacy, Universitas Sumatera Utara, 5 Jalan Almamater, USU-Kampus, Medan 20155, Indonesia. Email: urip@usu.ac.id

Received: 07 March 2018, Revised and Accepted: 25 March 2018

ABSTRACT

Objective: The objective of the study was to evaluate the effect of Picria fel-terrae on triglyceride and cholesterol levels in long-term duration.

Methods: The effect of ethanol extract of $P$. fel-terrae leaves was performed using white rats divided into several groups, which include control group, extract at doses of $125,250,500$, and $1000 \mathrm{mg} / \mathrm{kg}$ body weight. The extract at different doses was orally administered to the test animal for 90 days. Then, the triglyceride and cholesterol levels were measured.

Results: The ethanol extract of P. fel-terrae in long-term use did not affect the cholesterol level of male and female white rats. However, there was a significant increased in triglyceride level as compared to normal control $(\mathrm{p}<0.05)$.

Conclusion: The ethanol extract of P. fel-terrae increased triglyceride level only without increasing the level of cholesterol.

Keywords: Picria fel-terrae, Triglyceride, Cholesterol.

(C) 2018 The Authors. Published by Innovare Academic Sciences Pvt Ltd. This is an open access article under the CC BY license (http://creativecommons. org/licenses/by/4. 0/) DOI: http://dx.doi.org/10.22159/ajpcr.2018.v11s1.26618

\section{INTRODUCTION}

Cholesterol and triglycerides are the major lipids in the body. They are transported as lipoproteins which contain lipid and proteins. Plasma lipoproteins consist of phospholipid, cholesterol, triglyceride, and protein. Low-density lipoproteins (LDLs), very-LDLs, and high-density lipoproteins are three major classes of lipoproteins [1]. Abnormalities of plasma lipoproteins can result in hyperlipidemia includes hypercholesterolemia and hypertriglyceridemia. It is a predisposition to coronary disease and constitutes one of the major risk factors for coronary heart disease. Atherosclerosis may lead to the manifestations of ischemic heart disease [2].

Picria fel-terrae has been studied to have pharmacological activity as hepatoprotective, antidiabetic, and diuretic effects [3-5]. The previous study showed that this plant contains flavonoids, saponins, tannins, glycosides, and steroids/triterpenoid [6].

However, the effect of $P$. fel-terrae on cholesterol and triglycerides was seldom reported. Therefore, this study aimed to evaluate the effect of ethanol extract of $P$. fel-terrae on cholesterol and triglycerides levels of male and female white rats.

\section{METHODS}

\section{Materials}

The chemicals reagents used in this study were aquadest, ethanol, Na-CMC (Sodium-Carboxy Methyl Cellulose) (Sigma, USA). The tools used in this research were blender (Philips, Netherlands), rotary evaporator (Heidolph VV-300, Germany), animal balance (Presica Geniweigher GW-1500, Indonesia), and digital balance (Vibra, Japan).

Plant material, extraction, and characterization

The leaf of pugun tanoh (P. fel-terrae Lour.) was collected from Pancur Batu, Deli Serdang, Sumatera Utara. The plant identification was confirmed by Herbarium Medanese (MEDA) Universitas Sumatera Utara.

\section{Extraction procedure}

Fresh samples were washed, dried, and powdered in a grinder and stores in an airtight jar. An amount of $1000 \mathrm{~g}$ the dried leaf of pugun tanoh was extracted with maceration method using $10 \mathrm{~L}$ ethanol until discoloration. Then, the ethanol macerate was evaporated at $\pm 40^{\circ} \mathrm{C}$ in a rotary vacuum evaporator and thickened by heating in a water bath at $\pm 40^{\circ} \mathrm{C}$. The yield of ethanol extract of pugun tanoh leaf was $680 \mathrm{~g}(11.31 \%)$.

\section{Animals}

All treatments to the animal and procedure were evaluated by Animal Research Ethics Committees Faculty of Mathematics and Natural Science, Biological Department, University of Sumatera Utara.

\section{Analysis of triglyceride and cholesterol levels}

Animals were divided into five groups of females and males, each consisting of five rats:

1. Control of $\mathrm{Na}-\mathrm{CMC} 0.5 \% \mathrm{w} / \mathrm{v}$

2. Dose $125 \mathrm{mg} / \mathrm{kg}$ body weight (BW)

3. Dose $250 \mathrm{mg} / \mathrm{kg} \mathrm{BW}$

4. Dose $500 \mathrm{mg} / \mathrm{kg} \mathrm{BW}$

5. Dose $1000 \mathrm{mg} / \mathrm{kg} \mathrm{BW.}$

The treatment was administered orally at a single dose to the test animal for 90 days. At the end of the study, the blood was collected and inserted into microcentrifuge tubes and immediately centrifuged for $10 \mathrm{~min}$ at $3000 \mathrm{rpm}$. The serum was separated and stored in a freezer. The blood and serum samples were examined at Balai Laboratorium Kesehatan, Dinas Kesehatan Propinsi Sumatera Utara [7] OECD.

\section{Statistical analysis}

Data were analyzed using SPSS 17.0 with Kolmogorov-Smirnov normality test, two-way ANOVA, and Kruskal (Kruskal) Wallis to see differences between test groups with significance $(p>0.05)$.

\section{RESULTS}

Based on statistical analysis using two-way ANOVA (Table 1) it can be concluded that there is no significant difference $(\mathrm{p}>0.05)$ and post-hoc 
Table 1: Triglyceride and cholesterol levels of white rats

\begin{tabular}{llll}
\hline \multirow{2}{*}{ Group } & \multirow{2}{*}{ Gender } & \multicolumn{2}{c}{ Biochemical parameters $(\mathbf{m g} / \mathbf{d L})$} \\
\cline { 3 - 4 } & & Triglyceride & Cholesterol \\
\hline I & Female & $67.40 \pm 14.13$ & $65.60 \pm 19.68$ \\
& Male & $65.60 \pm 14.99$ & $58.40 \pm 12.79$ \\
II & Female & $117.20 \pm 20.46^{*}$ & $55.80 \pm 12.43$ \\
& Male & $118.40 \pm 48.21^{*}$ & $53.00 \pm 14.64$ \\
III & Female & $118.40 \pm 21.24^{*}$ & $43.60 \pm 8.76$ \\
& Male & $118.00 \pm 33.42^{*}$ & $73.40 \pm 23.38$ \\
IV & Femalew & $117.40 \pm 56.71^{*}$ & $43.00 \pm 8.80$ \\
& Male & $116.75 \pm 28.25^{*}$ & $48.00 \pm 5.88$ \\
V & Female & $116.80 \pm 12.45^{*}$ & $57.20 \pm 23.85$ \\
& Male & $118.40 \pm 11.14^{*}$ & $50.40 \pm 14.97$ \\
\hline \multirow{2}{*}{ *Significantly different with the control group $(\mathrm{p}<0.05)$}
\end{tabular}

Tukey test showed that there was a significant difference of cholesterol levels between normal control group and extract group. However, there was an increase of triglyceride level in the treatment group.

\section{DISCUSSION}

The biochemical examination showed no effect on cholesterol level but significant effect on triglyceride level. The ethanol extract of P. fel-terrae at all doses increased the triglyceride level (116.75$118.40 \mathrm{mg} / \mathrm{dL}$ ) as compared to normal group (65.60-67.40 mg/dL) in both male and female rats. As shown in Table 1, the effect of the extract on triglyceride level was not in a dose-dependent manner. Duration and intensity of exposure to toxic substances also can affect the form and the toxicity of a particular material [8]. These biochemical responses that may be adaptive, if sustained, lead to change or pathological and biochemical disorder [9]. Based on the screening, pugun tanoh leaf has glycoside compounds, terpenoids, saponins, tannins, and flavonoids. Flavonoids are polyphenol compounds that act as antioxidants [10]. On this study, treatment was orally administrated for 90 days so that it could increase the concentration of flavonoids in the blood and organ targets. Increased of high concentration antioxidant can change antioxidants be free radicals (pro). High concentration of antioxidant may affect the rate of oxidation that causes oxidative stress in cells because there was an unbalance amount of oxidant and pro-oxidant [11]. Oxidative stress may impair the metabolism of triglyceride. Collectively, these data show that ethanol extract of $P$. fel-terrae induced a significant effect on triglyceride level.

\section{CONCLUSION}

Ethanolic extract of pugun tanoh leaf increased the level of triglyceride. Hence, may increase the risk of hypertriglyceridemia in long-term use.

\section{ACKNOWLEDGEMENT}

This work was supported by Ministry of Research, Technology and Higher Education of the Republic of Indonesia through DRPM research grant scheme with grant number 8/UN5.2.3.1/PPM/KP-DRPM/2017.

\section{REFERENCES}

1. Nirosha KK, Divya M, Vamsi S, Sadiq M. A review on hyperlipidemia. Int J Novel Trends Pharm Sci 2014;4:81-92.

2. Shattat GF. A review article on hyperlipidemia: Types, treatments and new drug targets. Biomed Pharmacol J 2014;7:399-409.

3. Marianne, Chrestella J, Ginting MA, Dalimunthe A, Nasution R. Hepatoprotective activity combination of Curanga fel-terrae Lou leaves and Curcuma heyneana valeton and zijprhizome in rat induced by a combination of rifampin and isoniazid. Int J Pharm Pharm Sci 2017;9:23-8.

4. Lindarto D, Syafril S, Zein U, Saragih A. The effect of dhawalsan-1 (Curanga fel-terrae [Lour.]) extract versus metformin on the metabolic and inflammatory characteristics of patients with newly diagnosed Type 2 diabetes mellitus. Asian J Pharm Clin Res 2016;9 Suppl 1:225-8.

5. Dalimunthe A, Harahap U, Rosidah, Nasution MP. Evaluation of diuretic activity of Picria fel-terrae Lour leaves extracts. Asian J Pharm Clin Res 2015;8:204-5.

6. Juwita NA, Harahap U, Dalimunthe A. Relaxation effect of ethanolic extract of Picria fel-terrae (Pugon tanoh) leaves on contraction of isolated rat's ileum contracted by serotonin. J Innov Pharm Biol Sci 2018;5:37-41.

7. OECD. Repeated Dose 90-day Oral Toxicity Study in Rodents TG No. $408 ; 2008$.

8. Gupta D, Bhardwaj S. Study of acute, subacute and chronic toxicity test. Int J Adv Res Pharm Bio Sci 2012;1:103-14.

9. Welty FK. How do elevated triglycerides and low hdl-cholesterol affect inflammation and atherothrombosis?. Curr Cardiol Rep 2013;15(9):400.

10. Pietta PG. Flavonoids as antioxidants. J Nat Prod 2000;63(7):1035-42.

11. Procházkováa $D$, Boušová $I$, Wilhelmováa N. Antioxidant and prooxidant properties of flavonoids. Fitoterapia, 2011; 82(4):513-23. 